\title{
Responding to the challenges of water security: the Eighth Phase of the International Hydrological Programme, 2014-2021
}

\section{B. JIMENEZ-CISNEROS}

Secretary, International Hydrological Programme and Director of the Division of Water Sciences, UNESCO, Paris, France b.jimenez-cisneros@unesco.org

\begin{abstract}
This paper presents the major water challenges at global, regional and local levels, including the need to adapt to climate change. It relates how the International Hydrological Programme (IHP) - an intergovernmental scientific programme - will respond in its Eighth Phase to the water-related risks and seize potential opportunities, thereby contributing to ensure Water Security at all levels. The Member States of UNESCO IHP periodically define priorities for research, technological development, innovation and education. To implement the priorities in a coordinated manner, the Member States can count on the team and the projects of IHP based at UNESCO, as well as on the "UNESCO Water Family", consisting to date of a Category 1 centre UNESCO-IHE located in the Netherlands; the World Water Assessment Programme, based in Italy, which produces the World Water Development Report of the United Nations; 30 Category 2 water centres under the auspices of UNESCO; and 35 water chairs in various parts of the world. Governments can access the powerful network of the UNESCO Water Family through IHP and its Intergovernmental Council.
\end{abstract}

\section{INTRODUCTION}

Water is a key resource for health, human development and ecosystems, and it is vital for the eradication of poverty, the promotion of gender equity and its contribution to food and energy security. However, billions of people in the world are affected by serious water-related challenges, such as scarcity, pollution, deficiency of supply and sanitation, floods, droughts, the irreversible extinction of ecosystems and the loss of ecosystems services. Scientific estimates indicate that four out of five citizens $(80 \%)$ of the planet are directly or indirectly exposed to high levels of threat to water security (Vörösmarty et al. 2010). To partially face these challenges, in 2010 the United Nations General Assembly (UNGA) recognized the access to clean water and sanitation as a human right. In spite of this, the lack of access to water services remains a global issue. The Millennium Development Goal (MDG) target referring to the increase in water supply was reached in 2010, but there are still more than 600 million people that lack sustainable access to water services, among which $40 \%$, or close to 240 million people, live in Sub-Saharan Africa (out of a total population of 844 million in 2010; World Bank 2013), while millions of people receive water services that are deficient in the time, quality and/or the quantity provided. It is very likely that the MDG target on sanitation will not be reached in 2015, as there are still around 2.5 billion people without adequate sanitation services (WHO/UNICEF 2012). Here as well, Africa is particularly affected. In both cases, water supply and sanitation, the rural populations, women and children suffer most from the burden caused by water-related issues (IFAD 2014). This article describes how the International Hydrological Programme, a programme designed by the Member States of UNESCO, seeks to promote a coordinated international effort based on knowledge to reach current and future water security, as a response to risks and challenges, related or not to global changes.

\section{BACKGROUND}

The International Hydrological Programme (IHP) of the United Nations Educational Scientific and Cultural Organization (UNESCO) is an intergovernmental programme with the mandate to promote science, innovation, policies and the development of capacities related to the management of the hydrological cycle, including its societal component. To this end, IHP: (a) mobilizes scientific and innovation networks; (b) strengthens the interface between scientists and decision makers; and (c) develops institutional and human capacities (Fig. 1). The Programme was created in 1975 as a result of the International Hydrological Decade. Progressively, IHP became a multi- and transdisciplinary programme applying sciences and innovation to enhance the 


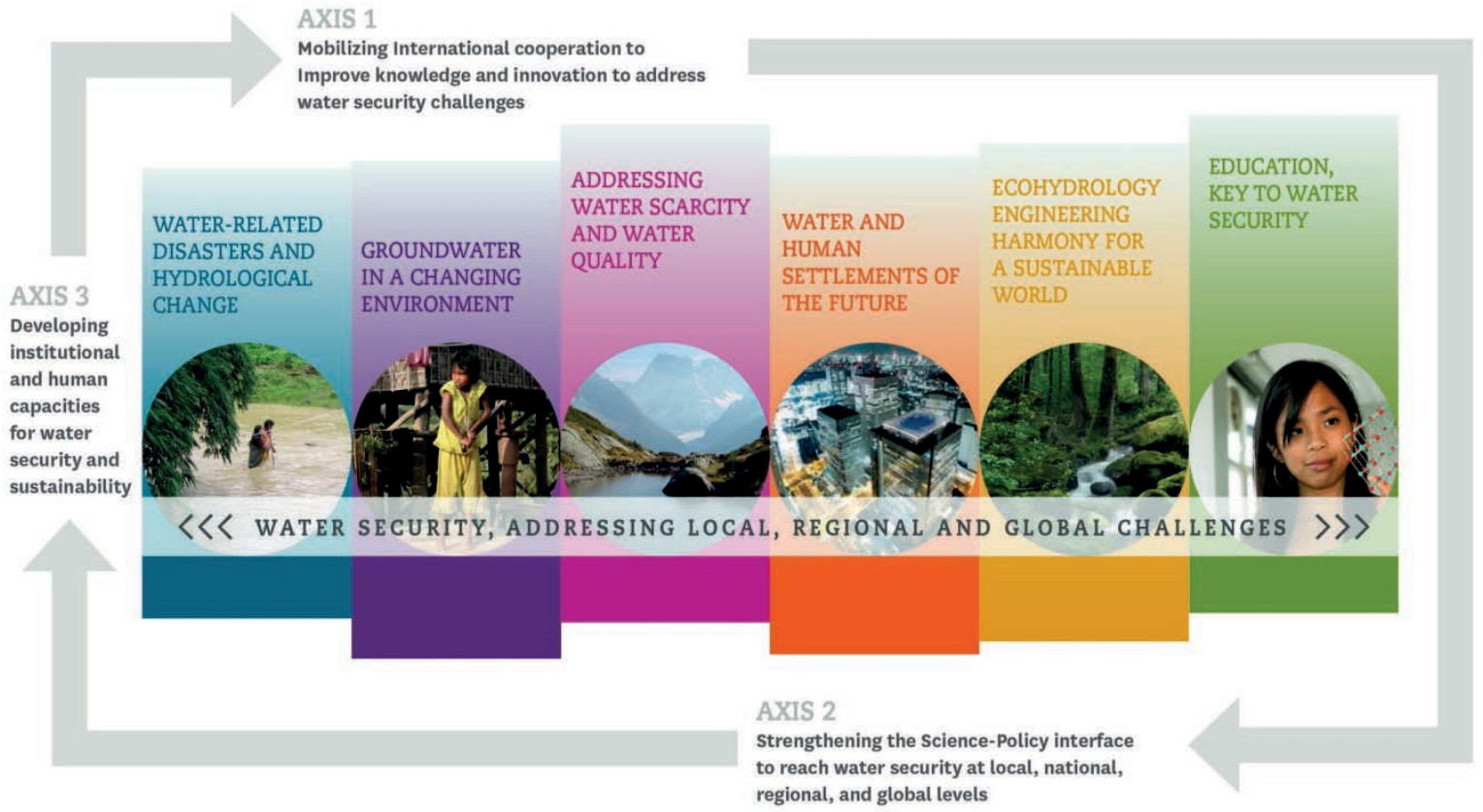

Fig. 1 Overview of themes and action axes of IHP-VIII, Water Security: Responses to Local, Regional and Global Challenges (2014-2021).

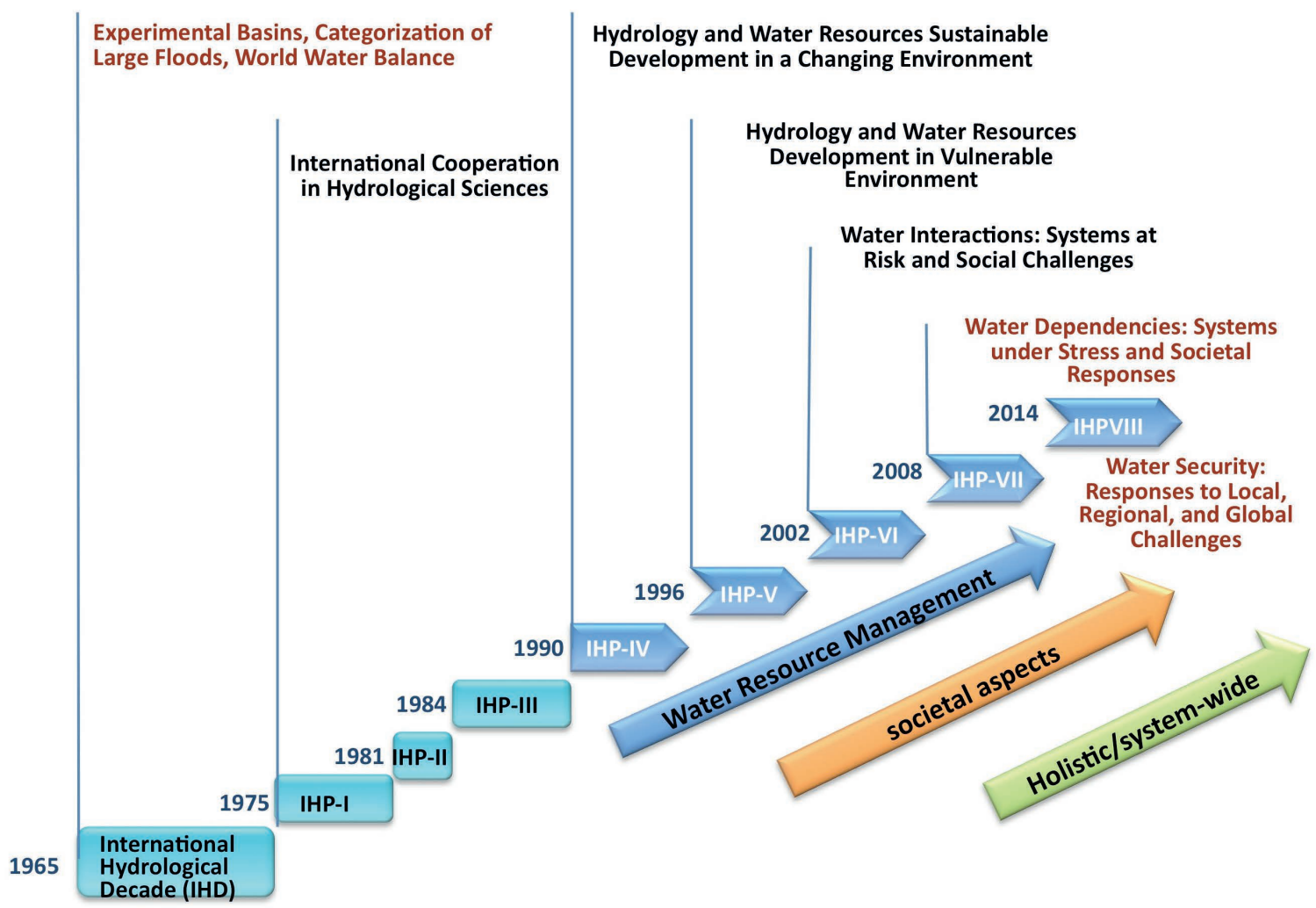

Fig. 2 Evolution of the International Hydrological Programme (IHP) of UNESCO.

management of water resources and to improve their governance (Fig. 2). The Programme is implemented in phases in order to match its content with the evolution of global issues. IHP's phases ran for six years, respectively, until 2014. Phase Eight of IHP, from 2014 to 2021 (IHPVIII) is planned for a duration of eight years. It is conceived, among other goals, to help 
implementation of the international post-2015 agenda and the forthcoming Sustainable Development Goals (SDG).

Humanity's destiny is closely linked to the way we use natural resources. To ensure "the future we want" (UNGA 2012), the management of natural resources must draw on science and innovation to be sustainable and wise. With this perspective, UNESCO's Member States dedicated IHP-VIII to "Water Security". While several definitions of water security exist, IHP conceived the only one which governments approved after intense technical and political discussions. The definition states that water security is "The capacity of a population to safeguard access to adequate quantities of water of acceptable quality for sustaining human and ecosystem health on a watershed basis, and to ensure efficient protection of life and property against water-related hazards - floods, landslides, land subsidence and droughts". Water security is threatened by several anthropogenic and natural factors such as population growth, land use, economic development behaviour patterns, physical and economic water scarcity and climate. All of these factors affect the availability of water for all uses and for environmental needs, access to related services and protection against disaster risks. According to the Fifth Report of the Intergovernmental Panel on Climate Change (IPCC 2014), water security and, as they are associated with it, food and energy security, are threatened by climate change. With growing emissions of greenhouse gases, most of these freshwater-related risks increase linearly until up to $3^{\circ} \mathrm{C}$ of global mean temperature rise (above pre-industrial levels at equilibrium), from which point risks increase exponentially. In response, IHP-VIII aims at achieving Water Security at local, regional and global levels by promoting mitigation and adaptation in order to control impacts from natural and anthropogenic sources of risks, through science and innovation. Additional details are provided in the following sections.

\section{MANAGING RISKS LINKED TO HYDROLOGICAL CHANGES AND WATER- RELATED DISASTERS}

It is estimated that $85 \%$ of the world's population lives on the more arid half of the Earth (Vörösmarty 2005) and that by $2030,50 \%$ of the world's population will live in high water stress areas (OECD 2008). Worse, 6 to 8 million people die each year of water-related disasters and diseases (UN-Water 2013). According to the IPCC (2014), climate change is expected to alter the water cycle. Projections at the global scale show greater variability of the effective water availability and higher risks of water-related disasters. The loss of snow cover and glaciers, which is currently being observed in the Arctic region, Eurasia and the Andes, will continue in the future. Snow cover and glaciers frequently are at the origin of the runoff from mountains. Mountains are especially important for water supply in high latitudes, where they represent $24 \%$ of the total land surface but yield $46 \%$ of the runoff. In glacierized catchments (except in Eastern Himalaya where the monsoon and ice melt seasons coincide), water runoffs reach their peak in summer, when the demand for water is higher. As a result of climate change, peak flow is now reached at the beginning of spring. Decreasing snowfall may lead to lower rivers and less groundwater recharge even if precipitation remains constant. The interaction of snowfall with aquifer recharge can be illustrated by an example of the southeast of the United States of America where snowmelt provides at least $40-70 \%$ of groundwater recharge, although only $25-50 \%$ of average annual precipitation falls as snow (Earman et al. 2006). Permafrost (soil that remains at or below the freezing point of water) acts like a water reservoir by modulating the water's availability. Over the first half of the 21 st century, the most optimistic RCP2.6 scenario of IPCC (2014) ${ }^{1}$, foresees a total permafrost area reduction of $20 \%$ in comparison with the 20th century area. IHP has launched an initiative to evaluate how changes in snow, glacier and permafrost conditions impact on water resources, to define the river and aquifer systems that will be the most affected and the means to adapt to these new conditions.

\footnotetext{
1 Representative Concentration Pathway: projected trajectory of greenhouse gas concentrations (not emissions) in the atmosphere. IPCC Fifth Assessment Report published in 2014 adopted four possible trajectories: "[...] they include a stringent mitigation scenario (RCP2.6), two intermediate scenarios (RCP4.5 and RCP6.0), and one scenario with very high greenhouse gas emissions (RCP8.5)." (IPCC 2014, 59).
} 
Water-related disasters are the result of very complex interactions between the ocean, the atmosphere and the land, but they also result from the exposure and vulnerability of human and natural systems. According to the IPCC (2014), data remains insufficient to demonstrate that the magnitude and frequency of floods have been modified due to anthropogenic climate change. However, it is clear that socio-economic loss due to floods has increased during the second half of the 20th century as a result of higher vulnerability. Regarding the future, all projections demonstrate that climate change will increase the frequency and intensity of floods, especially in South, Southeast and Northeast Asia, Tropical Africa and South America (IPCC 2014). Moreover, by the end of the 21st century, the number of people exposed to floods which occur once in a 100 years will be three times higher in the high-emissions and concentration scenario (RCP8.5) than in the low emission one (RCP2.6; IPCC, 2014). The most significant damages will be observed in Asia while, in Europe, annual damages will double in the 2080s for the SRES B2 scenario ${ }^{2}$ and will increase threefold in the $\mathrm{A} 2^{3}$ scenario, in comparison with the damages observed between 1961 and 1990 (6.4 billion euros and 200000 people affected; Feyen et al. 2012). The factors that increase the vulnerability and exposure of populations include deficient urban and territorial planning, the degradation of ecosystem services, inequity, poverty as well as policy makers' and society's inadequate perception of risk. Regarding droughts, the situation is similar: although it is not clear that they have increased in the past because of climate change, they are actually affecting more people than before; in the future, the situation will worsen because of higher frequency, intensity, exposure and vulnerability (IPCC 2014). The Mediterranean, Central Europe, the central region of North America and Southern Africa will be the most affected regions (OECD 2013). Droughts are one of the main limitations to development in Africa, which strongly depends on rainfed agriculture.

Alleviating the effects of uncertainty regarding the availability of water and of the occurrence and impacts of floods and droughts requires understanding of their causes, and improvement of crisis and risk management through the development of national policies. This is the fundamental objective of Theme 1 of IHP-VIII, Water-related Disasters and Hydrological Changes, details of which are shown in Table 1.

\section{MANAGING INVISIBLE WATER IN A SUSTAINABLE AND VISIBLE WAY}

Groundwater represents $98 \%$ of all unfrozen freshwater, it has multiple geological, geochemical and ecological functions and, in many settlements around the world, it is the only available source of water. For over 50 years, its use has dramatically increased because it is available even during drought seasons, is often of good quality and, in many parts of the world, is affordable (Llamas and Martínez-Santos 2005). Groundwater is fundamental for the survival of 1.5 billion people who live in rural areas, principally in poor regions of Africa and Asia. It is estimated to cover $50 \%$ of the global drinking water needs (Zektser and Margat 2004) and up to 50\% of the municipal water supply worldwide (WWDR 2009). Despite its importance, still little is known about groundwater as a resource; its management is often deficient and studies of effects of climate change on groundwater are scarce. It demands better knowledge of all aspects of groundwater to manage resources in such a way that they are not overexploited or polluted, and that societies are not inadequately dependent on them. All of this is part of the tasks of IHP-VIII's Theme 2, Groundwater in a Changing Environment, which also takes into account that groundwater is often a shared resource as it crosses political and geographical boundaries. In particular, the initiative ISARM (Internationally Shared Aquifer Resources Management) strives to improve the understanding of the scientific, social, economic, legal and environmental aspects of transboundary aquifers, while the World-wide Hydrogeological Mapping and Assessment Programme (WHYMAP; in close collaboration with the German Federal Institute for Geosciences and Natural Resources) collects, collates and visualizes information related to groundwater.

\footnotetext{
${ }^{2}$ Special Report on Emissions Scenarios (SRES) used in IPCC assessments before AR5; comparable to the intermediate scenario RCP6.0 (IPCC 2014, 59).

${ }^{3}$ SRES used in IPCC assessments before AR5; comparable to the high emissions scenario RCP8.5 (IPCC 2014, 59).
} 
Table 1 Focal areas of IHP-VIII ${ }^{4}$ Water Security - Responses to Local, Regional and Global Challenges.

\section{Theme 1: Water-related Disasters and} Hydrological Changes

1.1 Risk management as adaptation to global changes

1.2 Understanding coupled human and natural processes

1.3 Benefiting from global and local Earth observation systems

1.4 Addressing uncertainty and improving its communication

1.5 Improve scientific basis for hydrology and water sciences for preparation and response to extreme hydrological events

Theme 3: Addressing Water Scarcity and Quality

3.1 Improving governance, planning, management, allocation, and efficient use of water resources

3.2 Addressing present water scarcity and developing foresight to prevent undesirable trends

3.3 Tools for stakeholders involvement and awareness, and conflict resolution

3.4 Addressing water quality and pollution issues within an IWRM framework (improving legal, policy, institutional and human capacity)

3.5 Innovative tools for safety of water supplies and controlling pollution

Theme 5: Ecohydrology, Engineering Harmony for a Sustainable World

5.1 Hydrological dimension of a catchment (identification of potential threats and opportunities for a sustainable development)

5.2 Shaping of the catchment ecological structure for ecosystem potential enhancement - biological productivity and biodiversity.

5.3 Ecohydrology system solution and ecological engineering for the enhancement of water and ecosystem resilience and ecosystem services

5.4 Urban ecohydrology - storm water purification and retention in the city landscape, potential for improvement of health and quality of life.

5.5 Ecohydrological regulation for sustaining and restoring continental to coastal connectivity and ecosystem functioning
Theme 2: Groundwater in a Changing

\section{Environment}

2.1 Enhancing sustainable groundwater resources management

2.2 Addressing strategies for management of aquifer recharge

2.3 Adapting to the impacts of climate change on aquifer systems

2.4 Promoting groundwater quality protection

2.5 Promoting management of transboundary aquifers

\section{Theme 4: Water and Human Settlements of} the Future

4.1 Game changing approaches and technologies

4.2 System wide changes for integrated management approaches

4.3 Institution and leadership for beneficiation and integration

4.4 Opportunities in emerging cities in developing countries

4.5 Integrated development in rural human settlement

\section{Theme 6: Water education, Key for Water} Security

6.1 Enhancing tertiary water education and professional capabilities in the water sector

6.2 Addressing vocational education and training of water technicians

6.3 Water education for children and youth

6.4 Promoting awareness of water issues through informal water education

6.5 Education for transboundary water cooperation and governance

\section{ENSURING EQUITABLE AND RELIABLE WATER AVAILABILITY}

Scarcity is the main water-related challenge of many regions, often limiting social and economic development. Water availability depends on the quantity of water but also its quality, as well as the timely and affordable access to an efficient service. Scarcity is due to both natural and anthropogenic factors, which include political aspects. Ensuring access to water implies most of the time the necessity to coordinate: $90 \%$ of the world's population depend on shared water resources, at least 145 countries have transboundary river basins and there are 445 transboundary aquifers, sometimes shared by up to four countries (GEF, UNEP, TWAP, 2014; IGRAC 2014). Global warming has an impact on water availability. Roughly, for each additional degree that the temperature increases, $7 \%$ more of the world population will have at least $20 \%$ less water at their disposal (IPCC 2014). Moreover, as temperatures increase, so will water demand for all uses,

\footnotetext{
${ }^{4}$ cf. http://www.unesco.org/new/en/natural-sciences/environment/water/ihp-viii-water-security/
} 
threatening not only water security but also energy and food security. Water quality is also affected - both directly and indirectly - by intense urbanization, demographic growth, as well as the intensive use of fertilizers and natural resources. Around $85 \%$ of wastewater is discharged into the environment without any sort of treatment. Because of climate change, pollution related to higher water temperatures (leading to eutrophication), intense rainfalls (dragging soil and air contaminants into water bodies) and droughts (lowering contaminant dilution) are expected to become more frequent and intense. As mentioned before, the panorama of future situations is complex. On the one hand, the impacts of climate change on water quality are frequently not linear (with some exceptions such as water temperature increase), on the other hand, the effects of many other causes of pollution must be added. Water supply services operators will have to face challenges linked to the loss of natural water storage in snow and glaciers, growing variation of water availability, increasing demand and intensifying competition around the resource. IHPVIII's Theme 3, Addressing Water Scarcity and Quality, encompasses these and additional aspects with a multi- and transdisciplinary scope to reach a holistic management of water, considering the interrelations between uses and users, quantity and quality, in an integrated manner. The objective is to foster sustainable water management to reach efficient and universal water availability and accessibility. Therefore, IHP strives to improve the knowledge base of the quantity, the quality and the uses of water, to develop effective mechanisms to forecast and control pollution, use water efficiently, match demand with availability, manage transboundary water resources, generate legal, social and economic tools to improve water governance and take appropriate decisions under scenarios of high uncertainty.

\section{PROVIDE ALL PEOPLE WITH WATER SERVICES TODAY AND TOMORROW}

Today, 750 million people lack access to safe water and many millions more have access only to a deficient service. At the same time, urbanization is growing rapidly and, in the next 40 years, cities are expected to receive 800000 additional inhabitants each week. This and the absolute or partial lack of services, as well as population and economic growth, have been and will continue to be the factors that demand higher and better water supply coverage. Also, the aging of urban hydraulic infrastructure is evident in many cities and will require significant investments for renovation. Moreover, the greater variability of the quality of the water entering drinking water treatment plants will decrease their efficiency and, during intense floods, it will be necessary to turn them off completely.

Worldwide rapid urbanization makes new ways necessary to conceive and operate public services, including water services. New approaches are required to optimize the joint management of water, land use and energy, as well as to decrease the water footprint of cities in order to control the transportation of contaminants into water; also, the transfer of pollutants among water, soil and air must be better understood. These new approaches are part of the objectives of IHP-VIII's Theme 4, Water and Human Settlements of the Future (Table 1). The Theme also includes water supply to rural areas.

\section{COMBINING ENGINEERING AND ECOLOGY FOR SUSTAINABLE WATER MANAGEMENT}

Higher climate instability, as well as unsustainable use of natural resources and economic growth, are additional reasons not only to stop environmental degradation but also to reverse it. Between 1970 and 2000, the freshwater species on the Living Planet Index decreased by 50\%, while, of the marine and terrestrial species, 30\% have disappeared (Millennium Ecosystem Assessment 2005). Global economics and urbanization have profoundly altered the natural environment, transforming it in many places into vast agricultural or productive lands with spots of highly modified urban areas. It is expected that in the future, the over-engineering of urban and agricultural landscapes will affect the ecological flow more intensely than any other anthropogenic cause. This situation is even worse under the conditions of climate change scenarios. The projections show that, by the 2050 s, the impact of climate change on river flow characteristics will be stronger than the impact 
produced by dam constructions and water withdrawals up to the year 2000 (IPCC 2014). From this perspective, water catchments should be managed considering their carrying capacity and harmonising it with uses and societal needs. IHP-VIII's Theme 5, Ecohydrology - Engineering Harmony for a Sustainable World, seeks to do this by harmoniously combining eco-hydrology and engineering solutions and making the best of both approaches. In this way, new methods will be developed to regulate environmental cycles, including the "new ecosystems", and to understand better the role that ecosystems play and can play to support human activities such as agriculture and cities. As part of Theme 5, it is planned to continue implementing Demonstration Projects that employ sustainable, transdisciplinary and innovative practices for water management. UNESCO has 30 demonstration projects, two of which are described in Box 1.

\section{Box 1 Demonstration Projects of Ecohydrology}

Developing ecohydrological methods in the Pilica River basin, Poland

This project is part of the network of 91 basins in 67 countries of the Hydrology for the Environment, Life and Policy (HELP) network, which favours integrated basin management through a network of experts and decision-makers in the legal, administrative and scientific fields. It addressed the ecological and health hazards resulting from eutrophication of the river reservoir system and toxic cyanobacterial blooms. Furthermore, it planned and implemented a range of ecological and technological measures to mitigate high nutrient loads that had rendered a downstream reservoir unfit for human consumption. Currently, the project is working on reducing nitrogen and phosphorus fluxes to reservoirs and the Baltic Sea, towards the implementation of the European Union's Water Framework Directive.

\section{Developing tools for water planning, Australia}

The project implemented critical water reforms in Australia, mainly through catchment-based water plans. It responded to and integrated, through working with communities and the government, the challenges of the planning process in South Australia, Queensland and the Northern Territory within diverse hydrological, ecological, social and cultural contexts. Among challenges, it addressed building community confidence in the planning process; providing effective methodologies for identifying indigenous values in water; and integrating socio-economic, cultural and ecological considerations in water allocation decisions. The process developed tools, including participatory groundwater visualization models addressing specific community needs and innovative agent-based models that identified environmental, social and economic values in wetlands through visual methods.

\section{CHANGING MINDSETS FOR SUSTAINABLE WATER MANAGEMENT}

For historical reasons, water management, as well as the administration of many other common goods, is done by means of compartmentalized models. The development of human capacities follows a similar pattern, separating studies by disciplines, issues and problems, often in a unidimensional manner. This has become a vicious cycle, wherein the professionals and the research results stemming from this process promote the preservation of institutions and policies that are isolated, creating ministries and offices that work independently, duplicate functions or even perform conflicting activities. To achieve Water Security, we must change this pattern and form new generations of professionals able to understand and manage water in an integrated manner and with a multi- and transdisciplinary approach. Therefore, IHP-VIII's Theme 6, Water Education: Key for Water Security, promotes a critical review of the education curriculum in hydrology from the most basic levels of education to the highest specializations and including the training of technicians (Table 1). This Theme also seeks to raise awareness in all sectors of society to achieve Water Security.

\section{IHP-VIII RESOURCES AVAILABLE TO MEMBER STATES}

The implementation of IHP-VIII is supported by a network of networks, often called the UNESCO Water Family (Fig. 3), and an important number of international initiatives (Box 2). Together, they represent more than 1500 experts worldwide. Indeed, in addition to the UNESCO staff specialized 


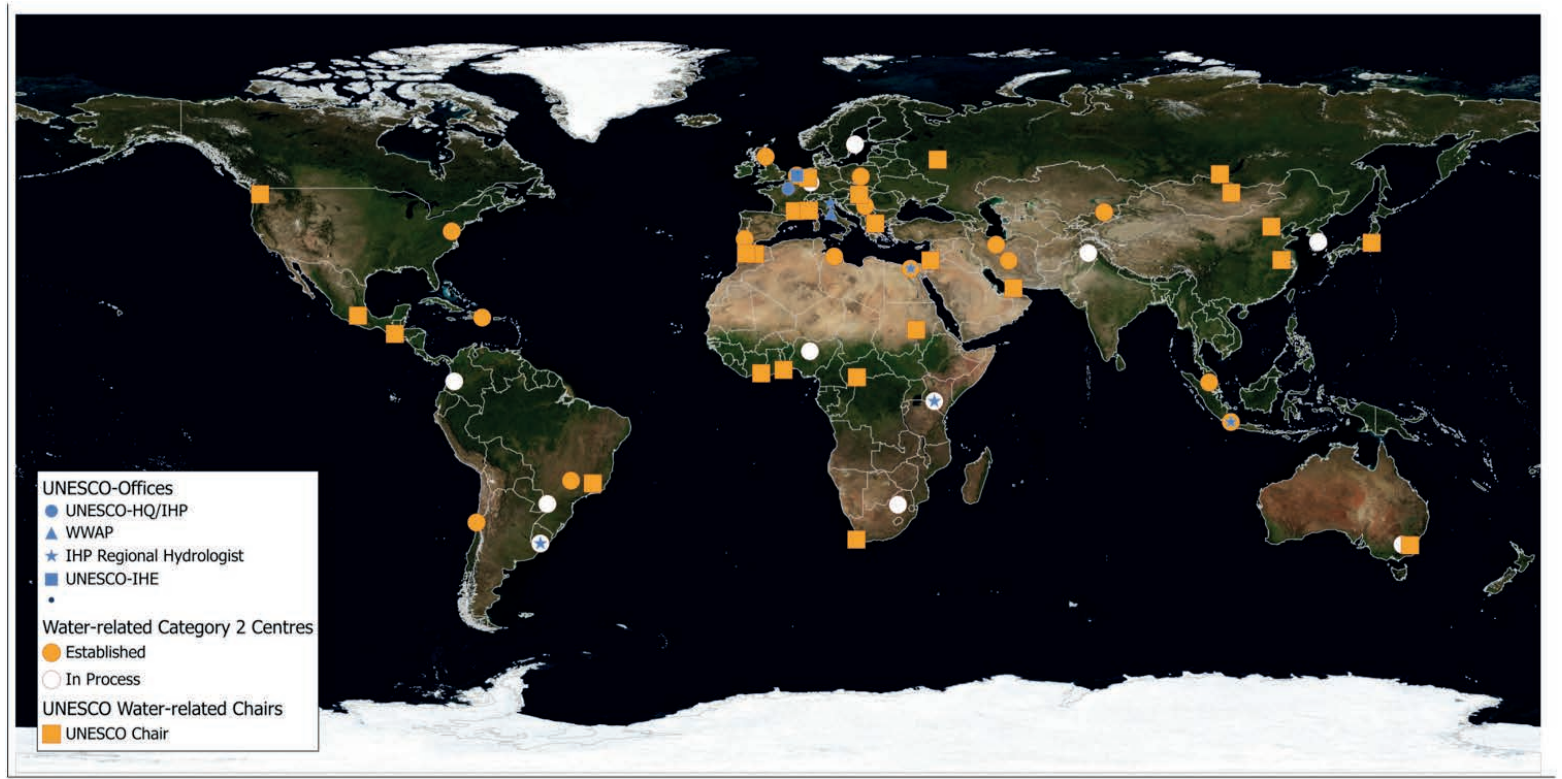

Fig. 3 The map of UNESCO's Water Family's worldwide network (six additional centres have been proposed and established since early 2014).

in water issues located both at the IHP Secretariat in our Paris headquarters and in the UNESCO field offices, IHP National Committees represent the programme in 169 Member States; the UNESCO-IHE Institute for Water Education in the Netherlands concentrates on higher education; the World Water Assessment Programme (WWAP), with its secretariat hosted and led by UNESCO located in Italy, produces the periodic World Water Development Report of the United Nations; close to 30 regional and international Category 2 centres under the auspices of UNESCO and 35 UNESCO Water Chairs actively contribute to research, training and the development of human capacity in specialized water-related fields. In other words, following the priorities defined by UNESCO's Member States, IHP serves to stimulate and coordinate international efforts to alleviate and prevent water problems at the global, regional and local levels. Indeed, this is an ingenious and very efficient way to face global challenges in a coordinated and collaborative manner.

\section{CONCLUSION}

Over time, water-related challenges have grown rather than diminished, getting more complex and pervasive. Now is the moment to act, as today Water Security is at risk. It is therefore important to better understand the nature and the causes of the problems, to grasp the risks they entail, how they can be controlled or prevented, and even, if possible, how to turn them into opportunities and benefits for the people. To this end, it is essential to develop and spread knowledge and to foster innovation, but also to use both in practice and through sound national and international policies. The International Hydrological Programme of UNESCO in its Eighth Phase is the tool at hand for the UN Member States to make this a reality, in a coordinated way and with global, regional and local impacts. The Programme can help develop flexible and adaptable solutions in various contexts that help in transforming societies of all cultures into societies resilient to global changes and increase their potential to develop in a sustainable manner. This very broad challenge can only be addressed through international cooperation and the rapprochement of science and innovation with policy makers. 


\section{Box 2 IHP's Transverse Programmes and Initiatives}

FRIEND (Flow Regimes from International Experimental and Network Data)

An international collaborative network of experts that aims to generate new understanding about regional hydrology and multi-scale water cycle processes.

\section{GRAPHIC (Groundwater Resources Assessment under the Pressures of Humanity and Climate Change)}

A UNESCO-led project seeking to improve our understanding of how groundwater interacts within the global water cycle, how it supports human activity and ecosystems, and how it responds to the complex dual pressures of human activity and climate change.

\section{G-WADI (Global Network on Water and Development Information in Arid Lands)}

A global network on water resources management in arid and semi-arid zones whose primary aim is to build an effective global community to promote international and regional cooperation in the arid and semi-arid areas.

HELP (Hydrology for the Environment, Life and Policy)

A new approach to integrated catchment management by building a framework for water law and policy experts, water resource managers and water scientists to work together on water-related problems.

\section{IDI (International Drought Initiative)}

A long-term initiative through which the research activities related to droughts as well as the development of capacities to address such events will be designed, coordinated and implemented.

\section{IFI (International Flood Initiative)}

An interagency initiative promoting an integrated approach to flood management which takes advantage of the benefits of floods and the use of flood plains, while reducing social, environmental and economic risks. Partners: the World Meteorological Organization (WMO), the United Nations University (UNU), the International Association of Hydrological Sciences (IAHS) and the International Strategy for Disaster Reduction (ISDR).

\section{ISARM (Internationally Shared Aquifer Resources Management)}

An initiative to set up a network of specialists and experts to compile a world inventory of transboundary aquifers and to develop wise practices and guidance tools concerning shared groundwater resources management.

\section{ISI (International Sediment Initiative)}

An initiative to assess erosion and sediment transport to marine, lake or reservoir environments aimed at the creation of a holistic approach for the remediation and conservation of surface waters, closely linking science with policy and management needs.

\section{JIIHP (Joint International Isotope Hydrology Programme)}

A programme facilitating the integration of isotopes in hydrological practices through the development of tools, inclusion of isotope hydrology in university curricula and support to programmes in water resources using isotope techniques.

\section{PCCP (From Potential Conflict to Cooperation Potential)}

A project facilitating multi-level and interdisciplinary dialogues in order to foster peace, cooperation and development related to the management of shared water resources.

\section{UWMP (Urban Water Management Programme)}

A programme that generates approaches, tools and guidelines which will allow cities to improve their knowledge, as well as analysis of the urban water situation to draw up more effective urban water management strategies.

\section{WHYMAP (World Hydrogeological Map)}

An initiative to collect, collate and visualize hydrogeological information at the global scale to convey groundwater-related information in a way appropriate for global discussion on water issues. 


\section{REFERENCES}

Earman, S., et al. (2006) Isotopic exchange between snow and atmospheric water vapor: Estimation of the snowmelt component of groundwater recharge in the South Western United States. Journal of Geophysical Research - Atmospheres 111(D9), D09302.

Feyen, L., et al. (2012) Fluvial flood risk in Europe in present and future climates. Climatic Change, 112(1), 47-62.

GEF, UNEP, TWAP (2014) Transboundary Waters - Humanity's Water Heritage http://www.unep.org/dewa/Portals/67/pdf/TWAP_A5_Brochure.pdf, consulted in September 2014.

IFAD (2014) Gender and water. Securing water for improved rural livelihoods: The multiple-uses system approach http://www.ifad.org/gender/thematic/water/gender_water.pdf, consulted in August 2014.

IGRAC (2014) Transboundary Aquifers of the World 2012. http:/www.un-igrac.org/publications/456\#, consulted in September 2014

IPCC (2014) Fifth Assessment Report (AR5)

http://ipcc.ch/pdf/assessment-report/ar5/syr/SYR_AR5_LONGERREPORT.pdf, consulted in September 2014.

Llamas, R. and Martinez-Santos P. (2005) Intensive groundwater use: silent revolution and potential source of social conflict. ASCE Journal of Water Resources Planning and Management. Editorial. 131(5), 337-341.

Millennium Ecosystem Assessment (2005) Ecosystems and Human Well-being: Biodiversity Synthesis. World Resources Institute, Washington, DC.

OECD (Organisation for Economic Cooperation and Development) (2008) OECD Environment Outlook to 2030. Paris: Organisation for Economic Co-operation and Development.

OECD (2013) OECD Studies on Water and Climate Change Adaptation Policies to Navigate Uncharted Waters. OECD Publishing, Business \& Economics.

United Nations General Assembly (UNGA) (2012) A/RES/66/288 Resolution adopted by the General Assembly on 27 July 2012, The future we want, http://daccess-dds-y.un.org/doc/UNDOC/GEN/N11/476/10/PDF/N1147610.pdf?OpenElement, consulted in September 2014

UN-Water (2013) Facts and Figures, http://www.unwater.org/water-cooperation-2013/water-cooperation/facts-and-figures/en/, consulted in September 2014.

Vörösmarty, C. J., Leveque, C. and Revenga, C. (2005) Fresh Water. In: Millennium Ecosystem Assessment, Volume 1, Conditions and Trends Working Group Report. Washington, DC: Island Press.

Vörösmarty, C. J., et al. (2010) Global threats to human water security and river biodiversity. Nature 467, 555-561

WHO/UNICEF Joint Monitoring Programme (JMP) for Water Supply and Sanitation (2012) Progress on Sanitation and Drinking-Water, http://www.unicef.org/media/files/JMPreport2012.pdf, consulted in September 2014.

World Bank (2013) Africa Development Indicators, http://data.worldbank.org/data-catalog/africa-development-indicators, consulted in November 2014.

World Water Assessment Programme (2009) The United Nations World Water Development Report 3: Water in a Changing World. Paris: UNESCO, and London: Earthscan.

Zektser, I. and Margat, J. (2004) Groundwater Resources of the World and Their Use. Paris: United Nations Educational, Scientific, and Cultural Organization-International Hydrological Programme. 